\title{
The concept of quasineutrons and the synthesis of zinc from the extraction of a part of the material of copper electrodes during electric current discharges in an aqueous solution of $\mathrm{NaCl}$
}

\author{
M.P. Kashchenko ${ }^{\dagger, 1,2}$, V. F. Balakirev ${ }^{3}$, N. M. Kashchenko ${ }^{1}$, M. B. Smirnov², \\ Yu. L. Chepelev², V. V. Ilyushin², N. V. Nikolaeva ${ }^{4}$, V. G. Pushin ${ }^{1,4}$ \\ †mpk46@mail.ru \\ ${ }^{1}$ Ural Federal University n. a. the first President of Russia B. N. Yeltsin, 19 Mira St., Yekaterinburg, 620002, Russia \\ ${ }^{2}$ Ural State Forest Engineering University, 37 Sibirskii Tract, Yekaterinburg, 620100, Russia \\ ${ }^{3}$ The Institute of Metallurgy UB RAS, 101 Amundsen St., Yekaterinburg, 620016, Russia \\ ${ }^{4}$ Miheev Institute of Metal Physics UB RAS, 18 S. Kovalevskaya St., Yekaterinburg, 620990, Russia
}

\begin{abstract}
For aqueous solutions during the flow of intense electric currents, the formation of quasineutrons $(p+e)$, bound states of protons $p$ and electrons $e$, should be typical. Then, as the simplest products of nuclear reactions, one can expect the formation of elements that are adjacent (in the periodic table) to the elements in the electrodes. In the experimental setup, pulsed electrical discharges are carried out in an aqueous solution of $\mathrm{NaCl}$ with a concentration of $0.1 \mathrm{~g} / \mathrm{l}$ using an oscillatory circuit tuned to resonance with the supply voltage $(220 \mathrm{~V}, 50 \mathrm{~Hz})$. As a material for hollow tubular electrodes, commercial copper was used. The starting potential difference is $650 \mathrm{~V}$. The discharges were accompanied by precipitation. Along with the products of erosion of electrodes $(\mathrm{Cu})$, there are particles with a significant proportion of zinc, the content of which varies widely, sometimes exceeding the copper content. This result testifies in favor of the existence of quasineutron states allowing the proton to approach distances of the order of the critical radius $R_{c} \sim 10^{-13} \mathrm{~m}$ for capturing the proton by the copper core. Particles containing nickel along with copper and zinc were also found. This can indicate both electronic capture with the formation of the Ni63 isotope (half-life $T \approx 100$ years) and capture of the quasineutron with the formation of Cu64 ( $T \approx 12.7$ hours) followed by electronic capture and the formation of Ni64. The abundance of particles containing zinc (without Ni) demonstrates the preference for proton capture.
\end{abstract}

Keywords: electrolysis, erosion of electrodes, quasi-neutron states, zinc synthesis.

УДК: 539.17

\section{Концепция квазинейтронов и синтез цинка}

\section{при экстрагировании части материала медных электродов}

в ходе разрядов электрического тока в водном растворе $\mathrm{NaCl}$

Кащенко М.П. ${ }^{1,2}$, Балакирев В. Ф. ${ }^{3}$, Кащенко Н. М. ${ }^{1}$, Смирнов М. Б. ${ }^{2}$,

Чепелев Ю. Л. ${ }^{2}$, Илюшин В. В. ${ }^{2}$, Николаева Н. В. ${ }^{4}$, Пушин В. Г. ${ }^{1,4}$

${ }^{1}$ Уральский федеральный университет им. первого президента России Б. Н. Ельцина, ул. Мира, 19, Екатеринбург, 620002, Россия

${ }^{2}$ Уральский государственный лесотехнический университет, Сибирский тракт, 37, Екатеринбург, 620100, Россия

${ }^{3}$ Институт металлургии УрО РАН, ул. Амундсена, 101, Екатеринбург, 620016, Россия

${ }^{4}$ Институт физики металлов им. М.Н. Михеева, УрО РАН, ул. С. Ковалевской, 18, Екатеринбург, 620990, Россия

Для водных растворов при протекании интенсивных электрических токов должно быть типичным образование квазинейтронов $(p+e)-$ связанных состояний протонов $p$ и электронов $e$. Тогда в качестве простейших продуктов 
ядерных реакций можно ожидать образование элементов, являющихся соседними (в таблице Менделеева) с элементами в составе электродов. В экспериментальной установке осуществляются импульсные электрические разряды в водном растворе $\mathrm{NaCl}$ с концентрацией 0.1 г/л с использованием колебательного контура, настроенного в резонанс с питающим напряжением $(220$ В, 50 Гц). В качестве материала полых трубчатых электродов применялась техническая медь. Стартовая разность потенциалов 650 В. Разряды сопровождались выпадением осадка. Наряду с продуктами эрозии электродов $(\mathrm{Cu})$, имеются частицы со значительной долей цинка, содержание которого варьируется в широких пределах, иногда превосходя содержания меди. Данный результат свидетельствует в пользу существования квазинейтронных состояний, позволяющих протону приблизиться на расстояния порядка критических $R_{c} \sim 10^{-13}$ м для захвата протона ядром меди. Найдены также частицы, содержащие, наряду с медью и цинком, никель. Это может указывать как на электронный захват с образованием изотопа Ni63 (период полураспада $T \approx 100$ лет), так и на захват квазинейтрона с образованием Cu64 (T $\approx 12.7$ часа), с последующим электронным захватом и образованием Ni64. Обилие частиц, содержащих цинк (без Ni), демонстрирует предпочтительность протонного захвата.

Ключевые слова: электролиз, эрозия электродов, квазинейтронные состояния, синтез цинка.

\section{Introduction}

The original installation of plasma water electrolysis demonstrated, according to [1] (Chapter 4 in [1]), an example of the implementation of low-energy nuclear reactions for the synthesis of chemical elements with low erosion of the electrodes. In [1], the synthesis was associated with the appearance of a stable "plasmoid" between electrodes spaced at a distance of $(1-1.5) D$, where $D$ is the internal diameter of the hollow electrodes $(D \leq 50 \mathrm{~mm})$. A possible explanation of the synthesis mechanism requires an expansion $[2,3]$ of traditional ideas. At the same time, to restore and improve the technology of synthesis of elements, it is advisable to increase the base of experimental data and interpret them using the simplified methodology [4] that we used in [5]. In this work, as in [5], pulsed electric discharges were carried out in an aqueous $\mathrm{NaCl}$ solution (with a concentration of $0.1 \mathrm{~g} / \mathrm{L})$ using an oscillatory circuit tuned to a resonance with the supply voltage $(220 \mathrm{~V}, 50 \mathrm{~Hz})$. The starting potential difference between the hollow tubular electrodes was $650 \mathrm{~V}$. The gap between the electrodes was $\approx 0.7 \mathrm{~mm}$. The electrodes were arranged vertically. Between the upper and lower vessels, the water moved by gravity. Each series of discharges was accompanied, similarly to $[4,5]$, by the appearance of a portion of a liquid with a dark (black) color, followed by precipitation.

In [6], the concept of a quasineutron was introduced as a bound state of a proton and an electron that exists in a wide range of spatial scales and corresponding energies. It was emphasized in [7] that the presence of quasineutrons should be manifested in the simplest reaction for the synthesis of elements with a charge number $Z+1$ at a charge number $Z$ of the electrode material. In particular, zinc synthesis can be expected with copper electrodes. The brass electrodes that we used in [5] ( $\approx 64$ at.\% Cu, 36 at.\% $\mathrm{Zn})$ mask to some extent the expected effect of zinc synthesis, which was not discussed in [5] like the synthesis of other more massive elements. Therefore, in this work, technical copper $(\approx 98$ at.\% $\mathrm{Cu})$ was used as the material of hollow tubular electrodes.

The main goal of the work is to analyze (by the standard method [8]) the chemical composition of solid powder fragments obtained after electrolysis to detect, in particular zinc, the synthesis of which is expected as a result of the interaction of quasineutrons with copper ions extracted by electrode erosion.

\section{Variation of the zinc content in the chemical composition of the particles of the precipitated powder}

The initial chemical composition of the electrodes was carried out in several randomly selected chip areas of the material of industrial copper used in the manufacture of electrodes. One of the typical results corresponds, for example, to the composition (in at.\%) $97.61 \mathrm{Cu}, 0.63 \mathrm{Fe}$, $1.77 \mathrm{O}$. We emphasize that neither zinc nor nickel (with an accuracy of at least $0.1 \%$ ) was fixed in the composition of the electrode material.

Fig. 1 is an external view of a portion of powder, fixed on an adhesive tape.

The two particles we numbered radically differ in the zinc content. The composition of the particles is presented in Table 1.

Although in most powder particles the zinc content does not exceed the copper content (similar to the composition of particle 2 in Table 1), zinc-dominated particles are also observed. The composition of one of these particles is given in Table 2.

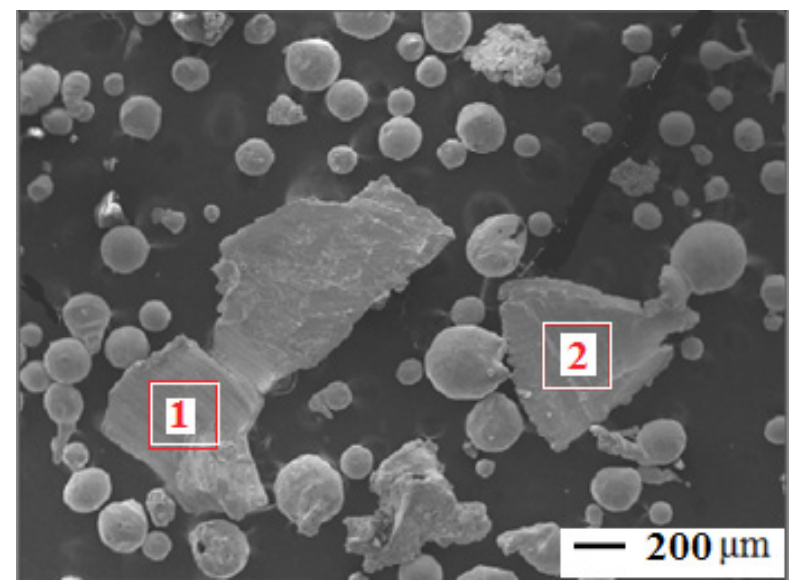

Fig. 1. The view of a fragment of powder, fixed on scotch tape, with an increase of $100 \times$, the numbering of the two particles is given by the authors. 
Table 1. The chemical composition of particles marked by numbers 1 and 2 in Fig. 1.

\begin{tabular}{|c|c|c|c|c|c|c|c|c|c|c|}
\hline & \multicolumn{3}{|c|}{ Particle 1 } & \multicolumn{5}{c|}{ Particle 2 } \\
\hline Element & $\mathrm{O}$ & $\mathrm{Mn}$ & $\mathrm{Fe}$ & $\mathrm{Cu}$ & $\mathrm{Zn}$ & $\mathrm{O}$ & $\mathrm{Mn}$ & $\mathrm{Fe}$ & $\mathrm{Cu}$ & $\mathrm{Zn}$ \\
\hline Wt.\% & 0.00 & 0.53 & 0.69 & 97.39 & 1.38 & 0.59 & 0.32 & 0.83 & 62.75 & 35.51 \\
\hline At.\% & 0.00 & 0.62 & 0.79 & 97.25 & 1.34 & 2.33 & 0.36 & 0.94 & 62.18 & 34.20 \\
\hline
\end{tabular}

Table 2. The chemical composition of a particle with a dominant zinc content.

\begin{tabular}{|c|c|c|c|c|c|c|c|c|c|}
\hline Element & $\mathrm{Al}$ & $\mathrm{Cl}$ & $\mathrm{Ti}$ & $\mathrm{Cr}$ & $\mathrm{Mn}$ & $\mathrm{Fe}$ & $\mathrm{Ni}$ & $\mathrm{Cu}$ & $\mathrm{Zn}$ \\
\hline Wt.\% & 0.45 & 1.11 & 0.20 & 0.16 & 0.29 & 14.63 & 0.48 & 16.80 & 65.88 \\
\hline At.\% & 1.04 & 1.95 & 0.25 & 0.19 & 0.33 & 16.35 & 0.51 & 16.49 & 62.87 \\
\hline
\end{tabular}

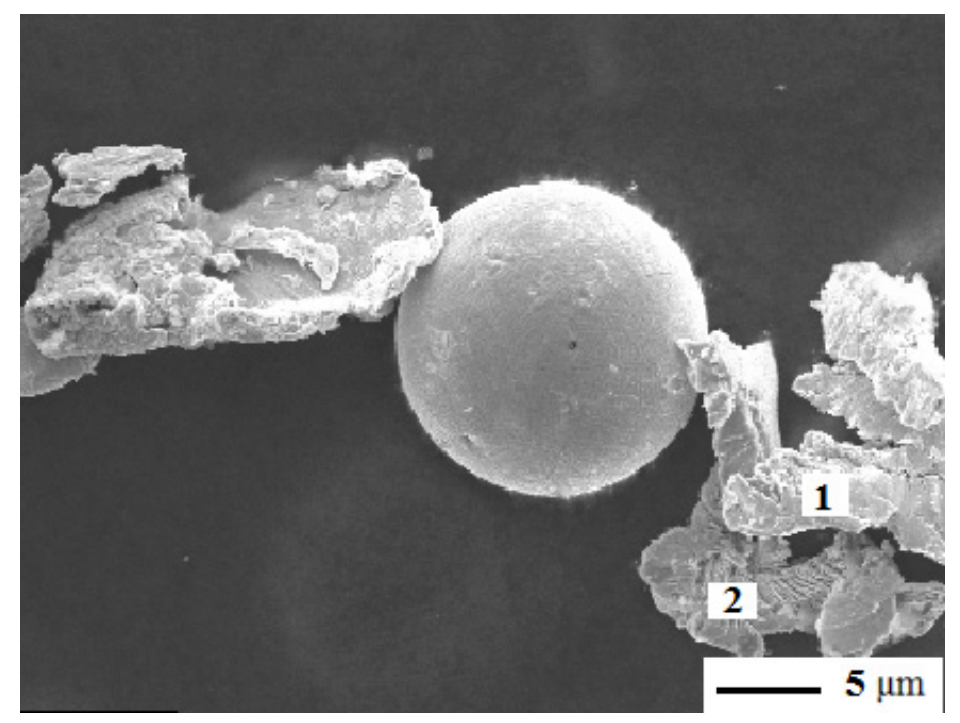

Fig. 2. View of the "chain" of ferromagnetic particles, with an increase of 5000x, the numbering of two particles is plotted by the authors.

The existence of particles dominated by iron was previously discussed by us [5]. Fig. 2 shows the "chain" of ferromagnetic particles (previously separated by us using a permanent magnet).

Particles with a high iron content predominate in this chain; however, there is also a particle with a nickel dominance marked by the number 1 . In the adjacent particle 2 , iron dominates (we recall that the particles formed independently at different points in time and were brought together during magnetic separation). For comparison, the compositions of these particles are presented in Table 3.

The dominance of $\mathrm{Ni}$ as well as the dominance of $\mathrm{Zn}$ is the exception rather than the rule. Particles with a $\mathrm{Zn}$ content comparable to that of copper in the absence or low content of $\mathrm{Ni}$ are fairly typical.

\section{Discussion of the results}

First, we list the simplest nuclear reactions involving isotopes of copper and a quasineutron.

Note that the synthesis of zinc, which has a wider set of stable isotopes Zn64 (48.6\%) Zn66 (27.9\%) Zn67 (4.1\%) Zn68 (18.8\%) than copper, is quite expected. There is also a long-lived isotope $\mathrm{Zn} 70(0.6 \%)$ with a half-life of $T \approx 5 \cdot 10^{14}$ years.

First of all, we indicate the main reactions of zinc synthesis during the fusion of copper nuclei with a proton escorted by an electron. Copper contains two stable isotopes Cu63 (69.17\%) Cu65 (30.83\%). Therefore, the synthesis of Zn64 and Zn66 isotopes can be realized.

$$
\begin{gathered}
\mathrm{Cu} 63+(p+e) \rightarrow \mathrm{Zn} 64+e, \Delta \varepsilon \approx 8.81 \mathrm{MэB} \\
\mathrm{Cu} 65+(p+e) \rightarrow \operatorname{Zn} 66+e, \quad \Delta \varepsilon \approx 8.925 \mathrm{MэB}
\end{gathered}
$$

It is easy to see that electron absorption by copper nuclei does not lead to stable nickel isotopes. The isotopes Ni63 ( $T \approx 100$ years) and Ni65 ( $T \approx 2.5$ hours) undergo $\beta$ decay, restoring the initial copper isotopes $\mathrm{Cu} 63$ and $\mathrm{Cu} 65$.

Note that the $\mathrm{Ni} 64$ isotope can also arise upon capture of the pseudoproton $(p+2 e)$ representing, according to Santilli [10], the bound state of a proton with two electrons

$$
\mathrm{Cu} 63+(p+2 e) \rightarrow \mathrm{Ni} 64+v,
$$

where $v$ is the symbol of the electron neutrino. The inclusion of one neutrino in the right-hand side suggests that the quasi-neutron state $(p+e)$, like the neutron, is associated with a zero lepton charge, while the pseudoproton $(p+2 e)$, like an electron, has a single lepton charge. As a result, the law of conservation of the lepton charge is fulfilled in reaction (3) [11]. We emphasize that, in contrast to the capture of quasineutrons by copper isotopes, zinc does not form. It is possible that a particle with a dominance of nickel and a low content of copper and zinc (particle 1 in Fig. 2 with the corresponding composition in Table 3) was formed mainly with the participation of pseudoprotons 
Table 3. The chemical composition of particles marked by numbers 1 and 2 in Fig. 2.

\begin{tabular}{|c|c|c|c|c|c|c|c|c|c|c|}
\hline & \multicolumn{9}{|c}{ Particle 1} & \multicolumn{5}{c|}{ Particle 2 } \\
\hline Element & $\mathrm{Al}$ & $\mathrm{Fe}$ & $\mathrm{Ni}$ & $\mathrm{Cu}$ & $\mathrm{Zn}$ & $\mathrm{Al}$ & $\mathrm{Fe}$ & $\mathrm{Ni}$ & $\mathrm{Cu}$ & $\mathrm{Zn}$ \\
\hline Wt.\% & 4.25 & 2.85 & 84.59 & 7.43 & 0.88 & 0.00 & 88.86 & 3.97 & 7.17 & 0.00 \\
\hline At.\% & 8.86 & 2.87 & 80.95 & 6.57 & 0.75 & 0.00 & 89.81 & 3.82 & 6.37 & 0.00 \\
\hline
\end{tabular}

by reaction (3). Considering, however, that the material of the electrodes could contain nickel as an impurity, this conclusion is conditional. However, the interaction of pseudoprotons with the Cu65 isotope leads to the formation of $\mathrm{Zn} 66$ :

$$
\begin{gathered}
\mathrm{Cu} 65+(p+2 e) \rightarrow \operatorname{Ni66}(T \approx 54.6 \mathrm{~h})+v, \\
\operatorname{Ni66} \rightarrow e+\widetilde{v}+\operatorname{Cu} 66(T \approx 5.12 \mathrm{~min}), \\
\operatorname{Cu} 66 \rightarrow e+\widetilde{v}+\operatorname{Zn} 66 .
\end{gathered}
$$

In (5) and (6), the symbol $\widetilde{v}$ refers to the electron antineutrino.

Obviously, after the appearance of Zn66, the absorption of quasineutrons can lead to the sequential formation of zinc isotopes with mass numbers 67 and 68, increasing the total zinc content. At the same time, the capture of a quasineutron by the $\mathrm{Zn} 64$ isotope would lead to the unstable $\mathrm{Zn} 65$ isotope ( $T \approx 244$ days), which, after electron capture, transfers to Cu65 reducing the total zinc content. Of course, the zinc formed mainly must contain the Zn64 and Zn66 isotopes whose formation according to (1) and (2) is due to the existence of two stable copper isotopes. If a significant amount of the $\mathrm{Zn68}$ isotope had arisen, then the reaction

$$
\mathrm{Zn} 68+(p+e) \rightarrow \mathrm{Ga} 69+e, \Delta \varepsilon \approx 6.6 \mathrm{MэB},
$$

gallium could form. No gallium was observed in this study, indicating a low content (or absence) of the Zn68 isotope. Since almost a fifth of natural zinc is in Zn68, gallium synthesis is quite probable if zinc electrodes are used in water electrolysis.

In our opinion, the results of the action of unipolar electromagnetic nanosecond pulses (see Chapter 5 in [1]) on aqueous solutions of $\mathrm{CuSO}_{4}$ and $\mathrm{ZnSO}_{4}$ salts also support the proposed mechanism of zinc synthesis. In the case of a lowered $\mathrm{pH} \approx 3.32$, after exposure for 16 minutes, a decrease (by approximately $0.2 \mathrm{mg} / \mathrm{L}$ ) of the content of copper ions and an increase (by approximately $0.2 \mathrm{mg} / \mathrm{L}$ ) of the concentration of zinc ions were observed. Recall that $\mathrm{pH}$ is related to the concentration of hydrogen ions $\left[\mathrm{H}^{+}\right]$with the ratio $\mathrm{pH}=-\log \left[\mathrm{H}^{+}\right]$, and a neutral medium corresponds to $\mathrm{pH}=7$ (water, at $25^{\circ} \mathrm{C}$ ). Therefore, when the $\mathrm{pH}$ changes from 7 to 3.32 , the concentration of hydrogen ions increases by about 4800 times. Then it is clear that a decrease in $\mathrm{pH}$ promotes zinc synthesis by increasing the probability of proton capture by copper nuclei in processes (1) and (2).

Returning to our experiment, we recall that copper alloys containing up to $39 \%$ zinc are copper-based solutions (the so-called single-phase $a$-brass). Therefore, it is extremely unlikely that the possible presence of small concentrations of dissolved zinc in the original industrial copper will lead to a multiple increase (tens of percent) of zinc in the sediment particles. On the contrary, the appearance of zinc due to the synthesis processes (1) and (2) is quite natural.

It is also natural to expect that the interaction of quasineutrons with mercury vapor will lead to the synthesis of gold, similar to how it was demonstrated during the bombardment of mercury by neutrons [12]. Due to the low content $(0.15 \%)$ of the Hg196 isotope in natural mercury, the reaction with the absorption of a proton with the absorption of a quasineutron and subsequent emission of an electron

$$
\mathrm{Hg} 196+(p+e) \rightarrow \mathrm{Au} 197+e
$$

is not commercially profitable (the history of the synthesis of gold from mercury is described in detail in [13]). However, as an option demonstrating the effectiveness of the participation of quasineutrons in the synthesis of elements, reaction (8) is certainly indicative. When setting up such an experiment, it should be borne in mind that, in addition to mercury toxicity, the absorption of a quasineutron by the Hg202 isotope (having a high content of $\approx 30 \%$ in natural mercury) gives the unstable $\mathrm{Hg} 203$ isotope $(T \approx 46.6$ days), which turns into $\beta$-decay toxic isotope Tl203.

It is worth noting that quasineutrons in fusion reactions during proton absorption have obvious advantages over neutrons: relative cheapness, lower penetrating power and lower levels of excitation of daughter nuclei, which reduces the probability of $\gamma$-radiation. Recall that in hadron mechanics [14] neutrons are contact-bound protons and electrons, and the fact of such a synthesis has been experimentally confirmed [15].

It seems very likely that it is the quasineutron states that play a decisive role in elementary synthesis reactions, involving the absorption of a proton or quasineutron in a matrix of crystalline solids saturated with hydrogen [16,17], especially when vibrational nonlinearity [18] is taken into account, which provides conditions for effective tunneling when approaching distances of the order of $R_{c} \sim 10^{-13} \mathrm{~m}$. Such reactions, in particular, ensure the functioning of the Rossi reactor [19] (see also [20]). Recall that in the reactor, during heating of crystalline nickel powder saturated with hydrogen, significant excess energy is released due to the "burning" of nickel isotopes. Of course, the presentation of the entire set of reactions in generators of this type deserves a separate discussion.

\section{Conclusion}

The analysis of the experimental data confirms that, in the case of copper electrodes during electric current discharges in water, zinc synthesis is observed, which testifies to the existence of quasineutron states that allow the reaction to capture a proton by a nucleus.

There are also grounds for interpreting reactions with the appearance of Ni64 as a consequence of the capture of quasineutrons by $\mathrm{Cu} 63$ nuclei with subsequent two-channel reactions with the formation of Ni64 and Zn64.

The expected result is gallium synthesis in the case of using zinc electrodes in the electrolysis of water. 
Aknowledgements. The authors are grateful to the participants of the thirteenth international Ural seminar "Radiation Physics of Metals and Alloys" for discussing some of the results of the work. The authors express their gratitude to the Ministry of Science and Higher Education of Russia for the support in the execution of state assignment No. 075-00243-20-01 of 08/26/2020 within the framework of the FEUG-2020-0013 theme "Environmental aspects of rational nature management".

\section{References}

1. V.F. Balakirev, V.V. Krymskiy, B.V. Bolotov et al. Interconversion of chemical elements. Ekaterinburg, UB RAS (2003) 97 p. (in Russian) [В.Ф. Балакирев, В. Крымский, Б. В. Болотов и др. Взаимопревращения химических элементов. Екатеринбург, УрО РАН (2003) 97c.]

2. M.P. Kashchenko, V.F. Balakirev. Letters on Materials. 7 (4), 380 (2017). $\underline{\text { Crossref }}$

3. M.P. Kashchenko, V.F. Balakirev. Letters on Materials. 8 (2), 152 (2018). (in Russian) [М.П. Кащенко, В.Ф. Балакирев. Письма о материалах. 8 (2), 152 (2018).] Crossref

4. V.A. Pan'kov, B.P. Kuzmin, Actual problems of modern science. (5), 117 (2008). (in Russian) [В.А. Паньков, Б. П. Кузьмин, Актуальные проблемы современной науки. (5), 117 (2008).]

5. M.P. Kashchenko, V.F. Balakirev, N.M. Kashchenko, M.B. Smirnov, Yu.L. Chepelev, V.V. Ilushin, N. V. Nikolaeva, V. G. Pushin. Letters on Materials. 10 (1), 66 (2020). (in Russian) [М. П. Кащенко, В. Ф. Балакирев, Н.М. Кащенко, М.Б. Смирнов, Ю.Л. Чепелев, В. В. Илюшин, Н. В. Николаева, В. Г. Пушин. Письма о материалах. 10 (1), 66 (2020).] Crossref

6. M.P. Kashchenko, N.M. Kashchenko. Letters on Materials. 9 (3), 316 (2019). (in Russian) [М. П. Кащенко, Н.М. Кащенко. Письма о материалах. 9 (3), 316 (2019).] Crossref

7. M. P. Kashchenko, N. M. Kashchenko. Letters on Materials. 10 (3), 266 (2020). (in Russian) [М.П. Кащенко,
Н.М. Кащенко. Письма о материалах. 10 (3), 266 (2020).] Crossref

8. M. M. Krishtal., I.S. Yasnikov et al. The world of physics and technology. Scanning electron microscopy and $\mathrm{X}$-ray microanalysis in practical examples. Moscow, Publishing house "Technosphere" (2009) 208 p. (in Russian) [М.М. Криштал., И.С. Ясников и др. Мир физики и техники. Сканирующая электронная микроскопия и рентгеноспектральный микроанализ в примерах практического применения. Москва, Изд-во «Техносфера» (2009) 208с.]

9. Table of Nuclides. Retrieved from the Website

10. R. M. Santilli. International Journal of Applied Physics and Mathematics. 9 (2), 72 (2019). Crossref

11. I. M. Kapitonov. Introduction to the physics of nuclei and particles. Moscow, LENAND (2017) 544 p. (in Russian) [И. М. Капитонов. Введение в физику ядра и частиц. Москва, ЛЕНАНД (2017) 544 с.]

12. M. G. Inghram, D. C. Hess Jr., R. J. Hayden. Phys. Rev. 71, 561 (1947). Crossref

13. K. Hoffmann. Kann man gold machen? Gauner, gaukler und gelehrte: aus der geschichte der chemischen elemente. Leipzig, Urania, Verlag (1982) 256 p.

14. R. M. Santilli. Foundations of Hadronic Chemistry. With Applications to New Clean Energies and Fuels. London, Kluwer Academic Publishers (2001) 554 p.

15. R. Norman, A. A. Bhalekar, S. Beghella, B. B. Buckley, J. Dunning-Davies, J. Rak, R.M. Santilli. American Journal of Modern Physics. 6 (4-1), 85 (2017). Crossref

16. D. D. Afonichev, T. I. Nazarova. Letters on Materials. 7 (1), 17 (2017). (in Russian) [Д. Д. Афоничев, Т. И. Назарова. Письма о материалах. 7 (1), 17 (2017).] Crossref

17. M. Fleischmann, S. Pons, M. Hawkins. J. Electroanal. Chem. 261, 301 (1989). Crossref

18. V. I. Dubinko, D. V. Laptev. Letters on Materials. 6 (1), 16 (2016). Crossref

19. S. Focardi, A. Rossi. Journal of Nuclear Physics. February 28 (2010).

20. A. G. Parkhomov. International Journal of Unconventional Science. 3 (7), 68 (2015). 